brazilianpoliticalsciencereview

\title{
ARTICLE
}

\section{Foreign aid and the governance of international financial organizations: the Brazilian-bloc case in the IMF and the World Bank*}

\author{
Laerte Apolinário Junior \\ Universidade de São Paulo, Brazil
}

This article examines the relationship between the Brazilian foreign aid, in the context of South-South Cooperation (SSC), and the formation of coalitions in the IMF and the World Bank. It explores whether the participation of a country in the bloc led by Brazil in the two organizations affects the volume of Brazilian foreign aid received by this country. As decisions are made by the Executive Board both in the IMF and the World Bank, the study focus on the alliances for the selection of representatives in those arenas. Results confirm the hypothesis that countries that take part in Brazilian coalition for the formation of both the IMF's and World Bank's Executive Board receive more foreign aid than those that do not.

Keywords: Brazilian foreign policy; foreign aid; international financial institutions; South-South cooperation.

(*) http://dx.doi.org/10.1590/1981-38212016000300006

For data replication, see bpsr.org.br/files/archives/Dataset_Apolinario 


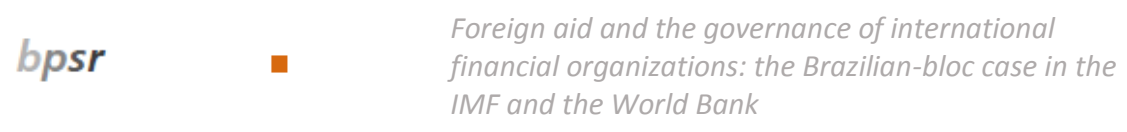

This article has as its object of study the International Development 1 Cooperation (IDC) initiatives undertaken by Brazil in the context of South-South Cooperation (SSC), having as its scope the years between 2003 and 2010, which correspond to the two mandates of ex-President Luiz Inácio Lula da Silva. In this period, South-South relations came to be seen as a priority on the agenda of Brazilian foreign policy, witnessing significant growth in the number of treaties of cooperation entered into by Brazil with developing countries².

The concept of SSC is not widely agreed upon, being used in general to designate a wide set of phenomena concerned with relations between developing countries. For some, SSC alludes to policies of consultation, dialogue and approximation between the countries of the South, as much on the bilateral level as on a multilateral level. However, the term has also been used to describe a more specific modality of SSC - South-South Development Cooperation (SSDC) referring to the actions made by a government with the intent of promoting economic development in under-developed countries, involving, as well as technical assistance, loans and donations (LEITE, 2012 and MILANI, 2014).

This study will employ the stricter concept of SSDC, using the terms foreign aid and IDC to refer to the same phenomenon. It is worth noting that the Brazilian government seeks to distance itself from the concept of foreign aid employed by the Development Assistance Committee of Organisation for Economic Co-operation and Development (DAC/OECD) 3 , calling its policy of foreign aid Brazilian Cooperation for International Development (COBRADI). Thus, Brazil rejects the terminology referring to "donor", "aid" and "assistance"4, preferring instead the definition given by the United Nations Conference on Trade and Development (UNCTAD), according to which cooperation refers to processes, institutions, accords, designed to promote political, economic, and technical cooperation between developing countries that seek common development and a horizontal relationship.

2 According to the Brazilian Cooperation Agency (ABC, Agência Brasileira de Cooperação), 30 projects and/or activities of cooperation were signed in 2004, 66 in 2005, 147 in 2006, 175 in 2007, 263 in 2008, 386 in 2009 and 472 in 2010.

${ }^{3}$ Multilateral organization created in September 1961, being an international forum made up of the main bilateral donors. It should be noted that not all members of the OECD are members of the DAC.

4 See the glossary of OECD statistical terms at $<$ http://stats.oecd.org/glossary/detail.asp?ID=6043>.

(2016) $10(3) \quad$ - $00006-2 / 29$ 
This difference, besides mere terminology, is accompanied by a diverse methodology related to the accountability of the spending on these policies. For example, contrary to the methodology utilized by the OECD, the forgiveness and renegotiation of debts, and concessionary loans with variable rates of return, do not enter into the balance sheets of the Brazilian government, kept by the Institute of Applied Economic Research (IPEA, Instituto de Pesquisa Econômica Aplicada). However, this study will use a wider concept of foreign assistance, defining this practice as "the voluntary transfer of the public funds of one government to another, with the objective of promoting development in the receiving country" (IPEA, 2013); the data from the AidData 3.0 project is used 5 .

Although there is a considerable literature on the determinants of foreign aid and of its efficacy, these studies are centered on the aid provided by developed countries; there is a lack of work on such cooperation delivered by emerging states, and in particular, Brazil. The present work, dialoguing with the studies that sought to analyze the patterns of the supply of traditional foreign aid (ALESINA and DOLLAR, 2000; BEARCE AND TIRONE, 2010; BERMEO, 2008; BERTHÉLEMY, 2006; DREHER, NUNNENKAMP and THIELE, 2008; KUZIEMKO AND WERKER, 2006; MCKINLEY AND LITTLE, 1977), seeks to investigate the determinants of the allocation of Brazilian foreign aid.

The Brazilian case is interesting for various reasons. Firstly, Brazil is one of a group of countries that have gone from recipients to donors of foreign aid in the international arena over the years ${ }^{6}$. Moreover, in contrast with the other donors of the OECD who presently follow the norms of DAC, the official position of the Brazilian government, under President Lula, was that the IDC undertaken by Brazil does not

${ }^{5}$ AidData is the result of a partnership formed in 2009 between three institutions - the College of William and Mary, the Development Gateway and the University of Brigham Young -, which has as its objective to make the available data on foreign aid more transparent and to aggregate information from various sources (AidData, 2011). It is worth noting that Brazilian aid data in AidData 3.0 do not cover the totality of the cooperation projects agreed to by Brazil during this period. The dataset of IPEA, the agency responsible for the systematization of this information, is not yet available to the general public. IPEA has released only some reports with aggregated values in relation to spending on these public policies in recent years, but has not released amounts for individual projects.

${ }^{6}$ According to a data crosscheck by Le Monde Diplomatique Brasil, the Brazilian government, between 2005 and 2009, supplied more international aid than it received from countries and multilateral agencies. It is worth mentioning that Brazil continues to receive foreign aid, this being one of the reasons that the country sought to distance itself from the official IDC terminology used by DAC/OECD. 


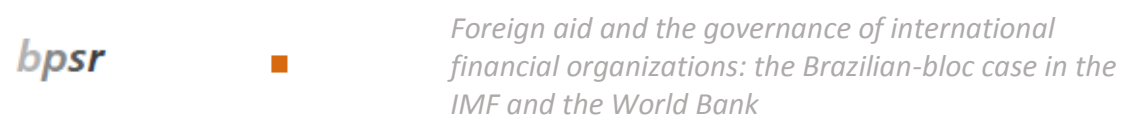

impose macroeconomic, environmental, governance or human rights conditionalities; it is based on the principle of non-interference in internal affairs; it is guided by the demands of recipient donors; and it do not envisage material gains and present less procedural demands (SOUZA, 2012).

Accordingly, the Lula's government claim is that it respects the principles of non-interference and sovereignty of partners, having suffered numerous and deep episodes of outside interference and violations of sovereignty throughout its history7. Therefore, it is necessary to verify to what extent the country utilizes cooperation as an instrument of its foreign policy, seeking counterparts of another nature, such as support in international institutions. Departing from the literature that analyzes how countries utilize foreign aid to realize foreign policy objectives, the present study analyzes if Brazil pursued its diplomatic objectives with its IDC policies, prioritizing the countries that supported it in international financial institutions. Therefore, we seek to verify if there is a relation between the donor of aid and the position of the recipient countries as regards Brazil in the governance issues of the International Monetary Fund and the World Bank.

Analysis of the Brazilian behavior, specifically, in these institutions is interesting for various reasons. First, Brazil has been a member of the IMF since its creation; historically, the country occupied a marginal role in the Fund, being part of a group of debtor countries with little voice in the organization. Only recently has Brazil come to be part of the select group of creditors of the institution, a fact that has permitted the country to gain a stronger position in the discussions on the governance of the organization. Second, Brazil is part of a group of emerging countries, together with Russia, India, China and South Africa, that are seeking reforms in the structures of governance of the international financial system; however, none of these countries are part of the coalitions led by Brazil in the IMF and the World Bank.

Third, besides the discourse of regional cooperation by Brazilian leaders in recent decades, not one Mercosur country is part of the Brazilian bloc in the sense

\footnotetext{
7 It is notable that in relation to Financial Cooperation, the National Development Bank (Banco Nacional do Desenvolvimento, BNDES) desired that the cooperation be reimbursable and demanded a series of conditionalities, such as the obligation that the resources be used to acquire Brazilian goods and services. Nevertheless, IPEA did not include this in its spending information in COBRADI (VIANA, 2015).
}

(2016) $10(3) \quad$ e0006-4/29


that if global economic governance was to be reformulated along regional lines, Brazil would be in a delicate situation, as the majority of its regional partners form part of the bloc led by Argentina and Uruguay. Furthermore, the apparent lack of historic ties between the members of the Brazilian bloc - composed presently of Cape Verde, Colombia, the Dominican Republic, Ecuador, the Philippines, Guyana, Haiti, Nicaragua, Panama, Suriname, East Timor, Trinidad and Tobago - and the heterogeneity of its members makes it an interesting case.

Moreover, as can be noted throughout history, these institutions were the focus of criticism for representing only the interests of the great powers and for not being transparent or accountable. Recently, various policy-makers around the world have argued that the crisis of legitimacy of the IMF could be solved through structural reforms in representation, in particular in its Executive Board. It is in this context that countries defend their positions with regard to international loans and other operations of the institution. Nonetheless, with respect to the centrality of the Executive Board in the governance of the IMF, the academic community has paid little attention to the representation of member states in this decision-making body.

Thus, this work, dialoguing with the literatures of foreign aid and of the governance of international financial institutions, will test the hypothesis that participation in the coalitions led by Brazil in the International Monetary Fund and the World Bank is one of the determinants for the receipt of Brazilian foreign assistance. The question then to be answered is: does there exist a relation between the foreign assistance supplied by Brazil and the composition of its bloc in international financial institutions?

\section{The institutional structure of the IMF and the World Bank}

The institutional structure of the IMF consists basically of the Board of Governors, the Executive Board, technical staff and the Managing Director. The Board of Governors is composed of a governor and a deputy for each member state. It is, in theory, the highest power inside the organization, but in practice, it delegates the majority of its functions to the Executive Board, except for those that are directly granted by the IMF Articles of Agreement. Thus, the Executive Board is in practice the most important organ in the institution, composed of twenty-four members, and is responsible for managing the general operations of the Fund and for electing the 


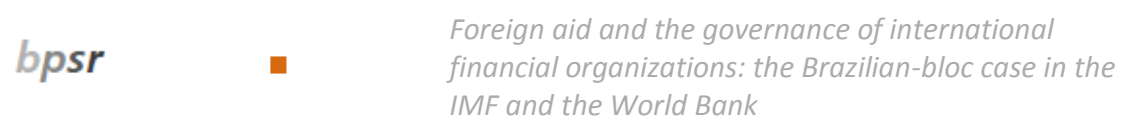

Managing Director, as well as exercising all of the powers delegated by the Board of Governors.

In the IMF, the voting power of each member state is determined by its participation quota, in which each member possesses 250 basic votes plus one more for every 100,000 Special Drawing Rights (SDR). This system of quotas also delineates the contributions of the states in the Fund, the availability of resources, and the distribution of SDRs between the members. The decision process in the IMF is based on the relative voting power of its members, where ordinary decisions need a simple majority to be approved, while some decisions need special majorities specified by the Articles of Agreement ${ }^{8}$.

Of the twenty-four chairs in the Executive Board, only five are occupied by countries that possess sufficient votes to appoint their representatives directly: the United States, Germany, Japan, France and the United Kingdom. However, recently, Russia, China and Saudi Arabia have also appointed their representatives without the help of other countries in virtue of the increase in their quotas of participation. The other countries occupy the remaining seventeen chairs through coalitions formed of various countries, but led by some in particular. These countries form alliances with the objective of electing a representative to act in the name of the countries that compose the bloc. These elections occur every two years and, although there are no formal rules for the formation of these coalitions, there are clear norms regarding the process by which these elections occur. Though the appointed directors can exercise the job for a time period determined by their countries, the elected directors provide their services for two years with the right to seek re-election.

Yet the World Bank is not a single international institution. With the passage of time, the organization has divided into five internal institutions: the International Bank for Reconstruction and Development (IBRD), the International Development Association (IDA), the International Finance Corporation (IFC), the Multilateral Investment Guarantee Agency (MIGA), the International Centre for Settlement of Investment Disputes (ICSID). In relation to its governance, the five institutions of the World Bank possess a power structure similar to that of the IMF, consisting basically

8 Since the second amendment to the Articles of Agreement of the IMF, adopted in 1977, two levels of qualified majority were agreed, $70 \%$ and $85 \%$. Thus, the United States is the only country with sufficient voting power to veto important decisions inside the organization. 
of a Board of Governors, the Board of Directors, the President, and organizational units of management. In practice, the composition of the blocs in the Board of Directors varies little relative to the blocs formed in the IMF and varies less still inside the agencies of the World Bank ${ }^{9}$.

Woods and Lombardi (2005) identify three patterns of governance that reflect the relations of power inside these coalitions. Some groups are strongly dominated by only one country, which holds the chair of the executive director and consequently leads decision-making in the bloc. A second group tends to be led by a small number of countries that alternate the position of executive director between them. And a third group, more egalitarian, is composed of states with similar economic capacity.

Some blocs are formed regionally, like the two blocs composed of African countries $^{10}$, which alternate the position of executive directors and deputy between themselves. Others are formed of states that possess cultural and historical ties amongst themselves, such as the blocs led by Spain and Canada ${ }^{11}$, which, although more geographically diverse, are also composed of countries that possess a common colonial legacy. However, other blocs have members with less obvious links, such as, for example, the Italian bloc ${ }^{12}$, the Austrian bloc ${ }^{13}$, that of Switzerland ${ }^{14}$ and the

\footnotetext{
${ }^{9}$ However, with regards to Brazil specifically, the object of this study, it may be noted that there are some differences in relation to the coalition formed in the IMF. In the IBRD, IFC and MIGA, the coalition led by Brazil consists presently of the Philippines, Colombia, the Dominican Republic, Ecuador, Haiti, Panama, Suriname, and Trinidad and Tobago. In the IDA, the coalition is formed of these same countries with the exception of Suriname.

10 One bloc is currently composed of Angola, Botswana, Burundi, Eritrea, Ethiopia, Gambia, Kenya, Lesotho, Liberia, Malawi, Mozambique, Namibia, Nigeria, Sierra Leone, South Africa, Sudan, South Sudan, Swaziland, Tanzania, Uganda, Zambia and Zimbabwe. The other consists of Benin, Burkina Faso, Cameroon, the Central African Republic, Chad, Comoros, the Democratic Republic of the Congo, the Republic of the Congo, the Ivory Coast, Djibouti, Equatorial Guinea, Gabon, Guinea, Mali, Mauritania, Mauritius, Nigeria, Rwanda, São Tomé and Príncipe, Senegal and Togo.

11 Currently made up of Antigua and Barbuda, the Bahamas, Barbados, Belize, Dominica, Granada, Ireland, Jamaica, St. Kitts and Nevis, St. Lucia, and Saint Vincent and the Grenadines.

12 Although it possesses sufficient votes to act of its own accord, the bloc acts in a consensual manner with its neighbors in the south of Europe, such as Greece, Malta, Portugal, San Marino and Albania.

${ }^{13}$ Formed of states such as Turkey, Belarus, the Czech Republic, Hungary, Kosovo, Slovakia and Slovenia.

${ }^{14}$ Composed of countries of with no apparent historical or cultural links between them, such as Azerbaijan, Kazakhstan, Kyrgyzstan, Poland, Serbia, Tajikistan and Turkmenistan.
} 


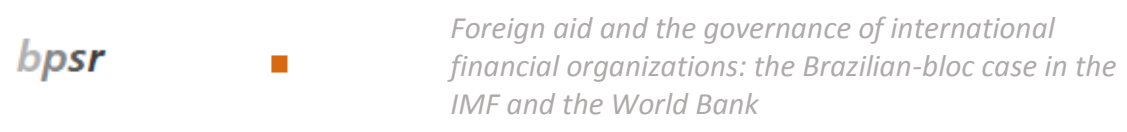

Brazilian bloc, which like the Swiss bloc, is formed of states that do not possess evident ties amongst themselves.

\section{Foreign aid in the international system}

The supply of foreign aid is not a recent phenomenon in international relations. Although there is no consensus on its definition, its origins are usually traced to the post-Second World War context, with the creation of the Marshall Plan and the Bretton Woods institutions. Note that the supply of aid was motivated by a combination of political, economic, social, geo-strategic, ideological, moral and ethical factors, and the weight of importance of each of these elements has varied over time (LANCASTER, 2007 and PUENTE, 2010).

In tandem with the development of IDC in the international arena, a family of literatures has sought to analyze the determinants of North-South Cooperation, identifying how these countries utilize foreign aid in order to realize their foreign policy objectives. One of the seminal works in this area is the study by McKinley and Little (1977) on the determinants of foreign aid provided by the USA, which structured the discussion around two alternative models to explain the allocation of foreign aid: the model of recipient needs and the model of donor interests. In the first model, the quantity of foreign aid supplied to each low-income country is thought to be proportional to the economic and social needs of these countries, such that the indicators that refer to foreign aid vary together with socioeconomic indicators for the recipients. In the second, the hypothesis is that the quantity of foreign aid received by whatever low-income country is thought to be proportional to the level of interest of the donor in the recipient country, with the interests of the donor being categorized in terms of political and economic interests.

Although these authors have structured the debate around two alternative models, it is clear that, to the extent that there is a series of important variables for explaining the supply of foreign aid, it is necessary to introduce them into the same model to avoid problems of omitted variable bias. Thus, a generation of studies has sought to analyze this phenomenon by using so-called 'hybrid' models, that is, combining the variables relating to donor motivations and donor interests in the same model. 
One of the most relevant recent studies in this literature is the study by Alesina and Dollar (2000) on the pattern of allocation of foreign aid of various donors. Their results show that foreign aid is guided more by political and strategic interests of the donors than the economic needs and policy performance in the recipient countries. Bearce and Tirone (2010) analyze the efficacy of foreign aid for local development in contrast to the interests of the donor in the recipient country and conclude that foreign aid can be effective for economic growth only when the strategic interests associated with the supply of aid are low for the donor. Schraeder et al. (1998) analyze bilateral aid flows from the United States, Japan, France and Sweden to the African continent in the 1980s and conclude that economic and military questions were decisive factors in the supply of aid and that humanitarian issues did not appear to be decisive for the donors analyzed.

Berthélemy (2006) studied the distribution of foreign aid supplied by various donor states over the decades of the 80 s and 90 s and his results show that the majority of the donors behave in a selfish manner as regards the supply of foreign aid, to the extent that not only do these countries utilize these policies in order to strengthen political connections with the recipients, but also to direct the aid toward their most significant commercial partners. Nonetheless, the results demonstrate that donors too take into consideration some of the needs and merits of the recipient countries, favoring on average the countries with the best governance and democracy indicators and those that have the largest growth rates.

Dreher, Nunnunkamp and Thiele (2008) examine if the foreign aid supplied by the United States influences the votes of recipient countries in the General Assembly of the United Nations (UNGA), finding strong empirical evidence that, besides economic interests, American foreign aid also serves to buy political influence in the recipients. In a similar vein, Kuziemko and Werker (2006) find empirical evidence that the non-permanent members of the UN Security Council receive more foreign aid from the United States, especially during moments in which the spotlight is focused on the Council.

Bermeo (2008) sought to investigate if there were significant changes in relation to the determinants of foreign aid with the end of the Cold War. In order to do so, she analyzed the allocation of foreign aid of four large donors, France, Japan, the United Kingdom and the United States over the last twenty years. She concluded 
that there are significant differences between recent flows of foreign aid and those that occurred during the 1980s. She notes that during the Cold War, foreign aid was primarily guided by military interests and that, currently, this issue occupies a lesser role in the motivations for supplying aid. She also points out that strategic interests continue to be determinants, although military issues have lost relevance to those of the economic sphere.

Vreeland (2011), dialoguing with this literature on the determinants of foreign aid, analyzed the relationship between aid provided by Switzerland and the composition of the Swiss coalition in the Board of Directors of the IMF and the World Bank. The results of his research corroborate the hypothesis that poor countries sell their support in global governance institutions with the objective of obtaining economic advantages such as foreign aid. Thus, the present study, based on the research design developed by Vreeland (2011), seeks to analyze if there exists a relation between Brazilian foreign aid and the composition of its coalition in the Board of Directors in the IMF and the World Bank, controlling for the effects of a series of variables that help to explain the allocation of bilateral foreign aid by Brazil in the international arena.

\section{Brazilian foreign aid}

Although this study adopts as its scope foreign aid supplied by Brazil in the period following 2003, encompassing the two Lula governments, it is worth highlighting the fact that IDC is not a creation of these administrations. Brazil has not been on the margins of global movements in relation to IDC, moving from recipient to donor during recent decades. However, it is from the time of the first government of Lula that SSDC gained prominence, being perceived with greater clarity as an instrument of Brazilian foreign policy, and being used as such. From 2003 onwards, the strategy of the integration of the country through the promotion of alliances and agreements with partners of the South, in order to reduce the asymmetries in relations with developed countries and increase Brazilian negotiating capacity, was strengthened (HIRST, LIMA and PINHEIRO, 2010; OLIVEIRA and ONUKI, 2012; PINHEIRO and GAIO, 2014; VIGEVANI and CEPALUNI, 2007).

Faria and Paradis (2013) claim that the "solidarity" character of the international integration strategy adopted by Brazil after Lula's arrival into power, 
characterized by the increase of foreign aid given to others by Brazil, can be explained by domestic, regional and systemic factors. Motives at the domestic level can be found in the principles of the Workers' Party (Partido dos Trabalhadores, PT) regarding a foreign policy that places priority on SSC; in the economic growth of the country during this period and in the success of domestic social policies that could be exported to other polities. The regional factors consist of the necessity of paying the costs of the desired regional leadership, especially due to rivalry with Venezuelan diplomacy at this time. And, lastly, the systemic motivations consist of the windows of opportunity open to Brazilian ambitions resulting from the North American policy of the War on Terror, the appearance of the BRICS as a political coalition, and the financial crisis of 2008.

Hirst, Lima and Pinheiro (2010) note that the cooperation carried out by Brazil combines foreign policy motives with the ability to attend to specific technical assistance demands from recipient states seeking to avoid repeating the logic of North-South aid. Through $\mathrm{ABC}$, the country has sought to construct horizontal cooperation, by means of actions that envisage building bridges of communication and the exchange of knowledge, and political and social allegiances with other developing countries. Thus, this effort coincides with the relevant changes in the country's international integration, motivated by new international ambitions, aspiring to expand the presence of the country in global negotiations, in the ambit of multilateral organizations and regimes and in regional issues.

Hirst (2011) highlights that, normatively, the IDC supplied by Brazil is based on the ideals of solidarity and in the exchange of common experiences, not possessing ties to commercial interests and foreign direct investment. Brazil seeks to promote the image that its cooperation differs from the traditional cooperation implemented historically by the countries of the North, to the extent that Brazilian cooperation is not guided by material interests. Thus, the principal objective of Brazilian development cooperation is the accumulation of soft power, in so far as that the country seeks to increase its legitimacy as a relevant actor in the international system, wishing to promote reforms in order to gain a voice in the institutions of global governance.

The official position is that, from 2004 on, cooperation agreements signed by Brazil in the context of the General Directives of Technical Cooperation between 
Developing Countries (CGPD), has been guided by the following guidelines: 01 . prioritizing technical cooperation programs that favor the intensification of relations between Brazil and its development partners, mainly with countries of priority interest for the Brazilian foreign policy; 02. support related projects, above all the national development priorities and projects of the recipient countries; 03 . channeling CGPD efforts toward projects that yield greater benefits in terms of influence, with an increasingly intensive multiplicative effect; 04. prioritize projects that have a greater scope for results; 05. support projects where there are national counterparts in the recipient and/or with the effective participation of partner institutions; 06. preferably, establish partnerships with genuinely national institutions ${ }^{15}$.

In light of present government guidelines, CPGD has been based on the following priorities: 01. commitments assumed on Presidential trips or those of the Chancellor; 02. South American countries; 03. Haiti; 04. African countries, especially the Portuguese-speaking African Countries (Países Africanos de Língua Oficial Portuguesa, PALOPS), and East Timor; 05. other countries of Latin America and the Caribbean; 06. support to the Community of Portuguese-speaking Countries (Comunidade dos Países de Língua Portuguesa, CPLP); and 07. increase triangular cooperation initiatives with developed countries and international organizations ${ }^{16}$.

Graph 01 illustrates the historical evolution of bilateral foreign aid supplied by Brazil during the 2000s, employing data from the AidData 3.0 project $^{17}$. As can be seen, Brazil came to systematically supply aid starting from the first mandate of President Lula. At this moment, South-South relations came to be a priority on the foreign policy agenda of Brazil, witnessing a significant increase in the number of cooperation agreements signed by Brazil with developing countries (HIRST, LIMA and PINHEIRO, 2010; OLIVEIRA and ONUKI, 2012).

\footnotetext{
15 Source: www.abc.gov.br. Accessed on March 10, 2016.

16 Source: www.abc.gov.br. Accessed on March 10, 2016.

17 These data include commitments of the form: subsidies, loans at favorable rates to multilateral agencies; development loans at the market rate; technical assistance; programs of transferred assistance by sector in the form of money or in kind and some capital investment activities. It is worth noting that the following is not considered foreign aid: military equipment and service; military debt stocks; credit for export support or trade financing; loan guarantees; flows of aid from NGOs, loans from funds held in the recipient country; foreign direct investment (FDI), bank loans without guarantees, portfolio investments and financing contributions from multilateral development organizations (AidData User's Guide, 2011).
} 
Graph 01. Evolution of Brazilian foreign aid (2003-2010)

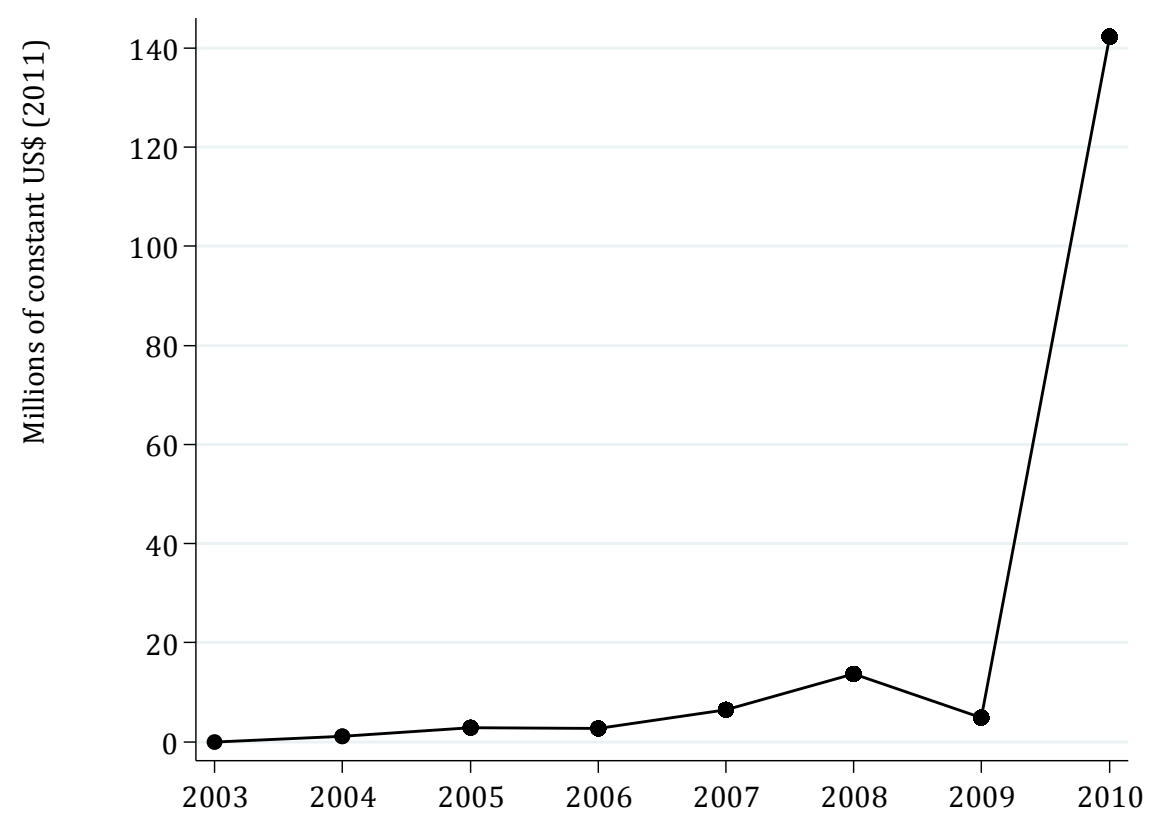

Source: AidData 3.0.

Note the inflection in the values supplied in 2009; in the period of the greatest escalation of the financial crisis, the country returned to providing significant amounts in 2010. This was a record year in the supply of foreign aid, in which Brazil sought to place itself among the global players by gaining ground over developed countries. It is noteworthy that these data were taken from the AidData 3.0 project, which does not encompass the totality of the cooperation projects entered into by Brazil in this period. However, the dataset from IPEA, the agency responsible for the systematization of these data, is still not available to the general public. Until now IPEA has released only some reports with aggregated values in relation to spending on these policies in recent years, and has not released the values by project.

By way of comparison, an attempt to replicate the first graph follows below, employing data made available by IPEA for the years of 2005 and 2010. In order to create this graph, spending on multilateral organizations was deducted from the values of cooperation by year. Note that although the pattern seems similar, the values are higher than those published by AidData. This occurs for two reasons. First, the AidData dataset is incomplete in relation to that of IPEA; second, the dataset from the IPEA reports do not discriminate between bilateral and multilateral cooperation for all modalities and for all years of the sample. 
Graph 02. Evolution of Brazilian foreign aid (2003-2010)

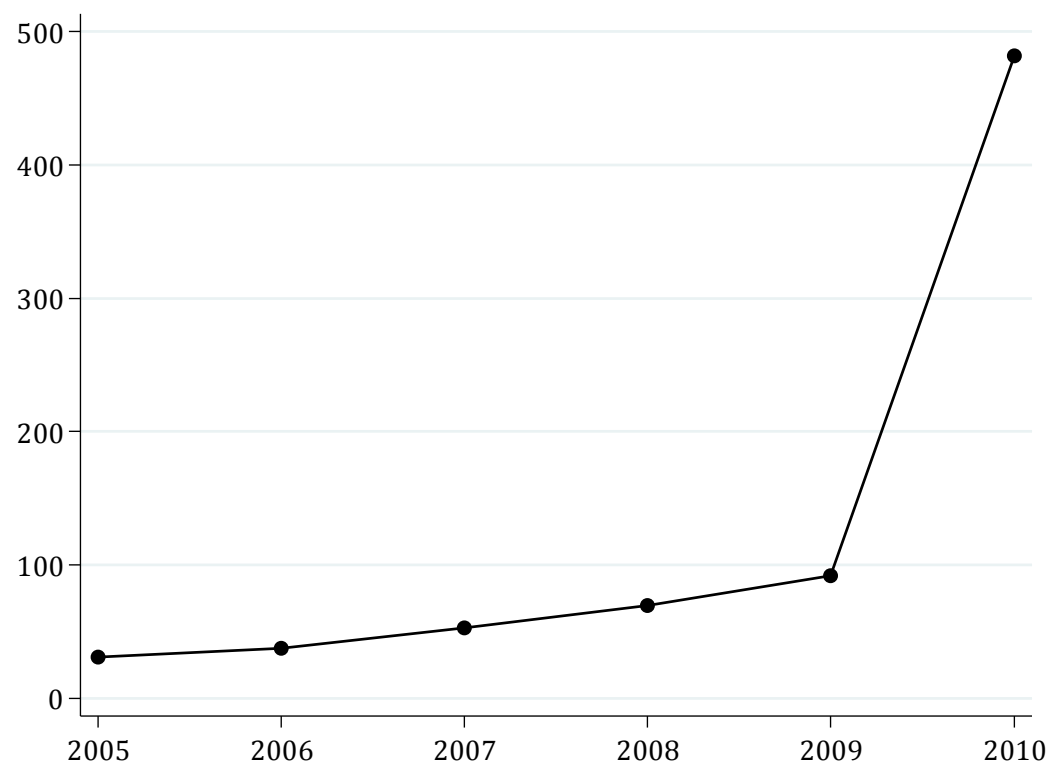

Source: IPEA, 2013.

Next, graph 03 displays the total amount of bilateral aid given by Brazil to each country. Note that the largest recipients are African and American countries, particularly those located in South and Central America, with Mozambique and Haiti being the largest beneficiaries. East Timor, a Portuguese-speaking country located in Southeast Asia, also appears as a significant recipient of Brazilian foreign aid. Due to IPEA not having made available the spreadsheets containing the values of spending on bilateral cooperation for each country between the years of 2005 and 2009, it is not possible to re-create graph 03 with IPEA data.

Graph 04 displays the total aid supplied by Brazil between 2003 and 2010, by the principal beneficiary sectors. Note how the projects referring to education were the priority during the period, totaling US\$37.8 million, followed by agricultural sectors, US\$ 20.6 million, and primary healthcare, at US\$ 19.3 million. It is notable that these graphs above only consider Brazilian bilateral foreign aid, and do not consider donations to international organizations and regions as a whole. 
Graph 03. Main Brazilian bilateral foreign aid recipients (2003-2010)

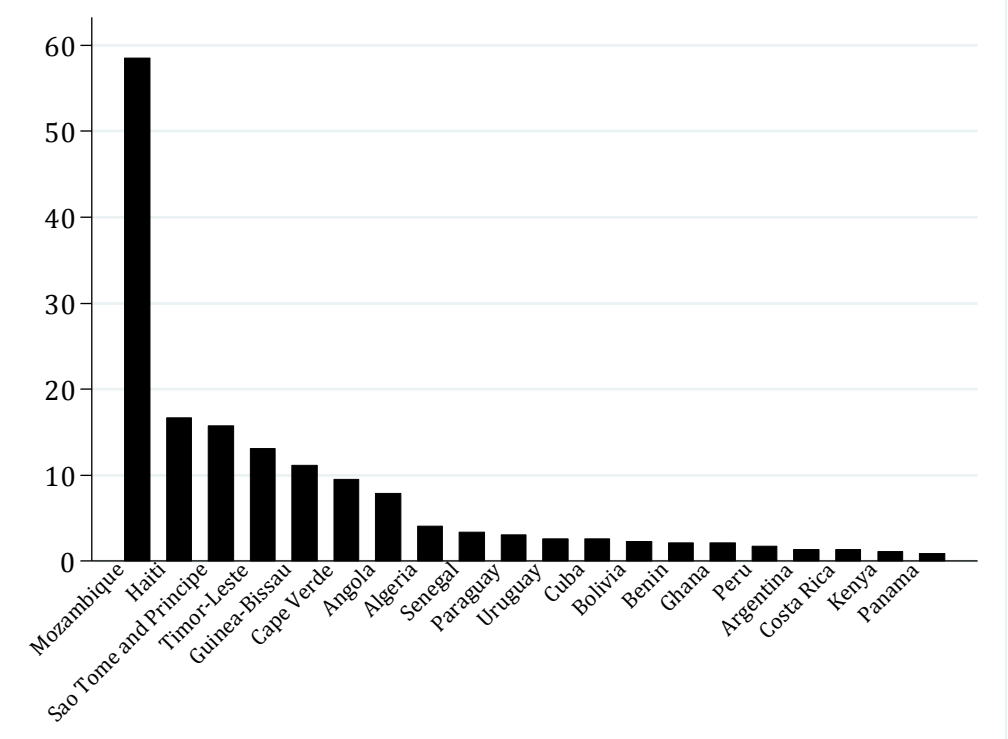

Source: AidData 3.0.

Graph 04. Brazilian foreign aid by sector (2003-2010)

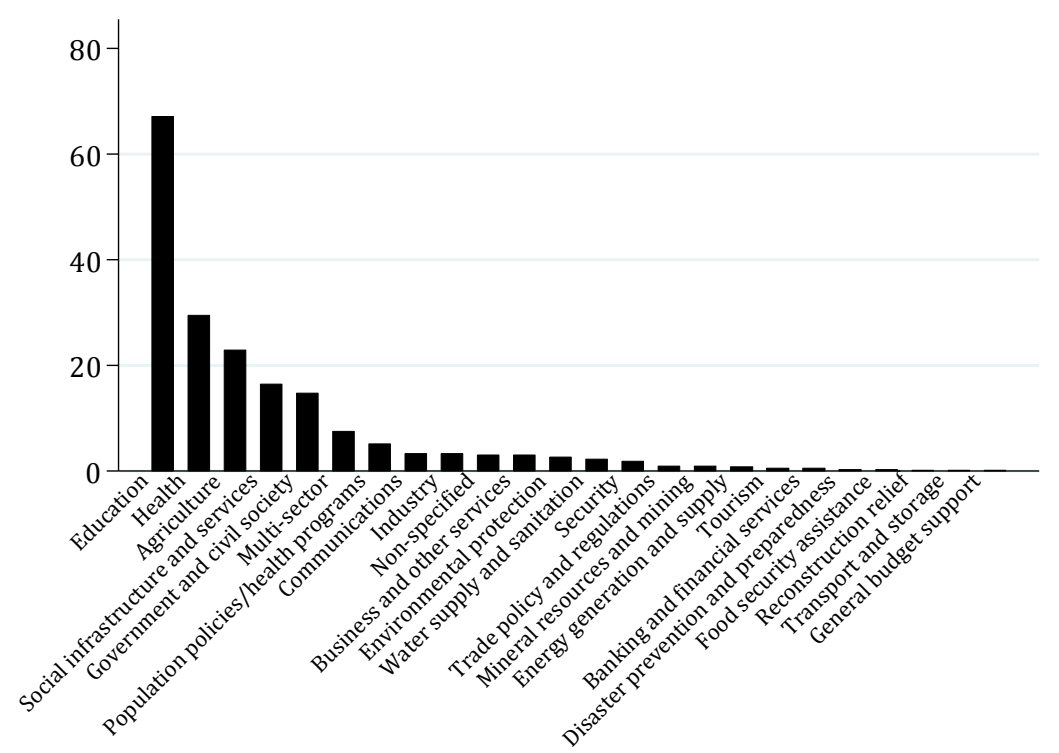

Source: AidData 3.0.

Once more, it is not possible to replicate this graph utilizing IPEA data because of the unavailability of quantitative data by sector. On the website of $A B C$, a pie-graph is available, showing the percentage of spending on cooperation by sector between 2000 and 2014. Nevertheless, the classification employed is too different to that of the AidData 3.0 project for a comparison to be possible. Regardless, a graph based on the data available on the website of $\mathrm{ABC}$ is shown below. 
Graph 05. Brazilian foreign aid by sector (2000-2014)

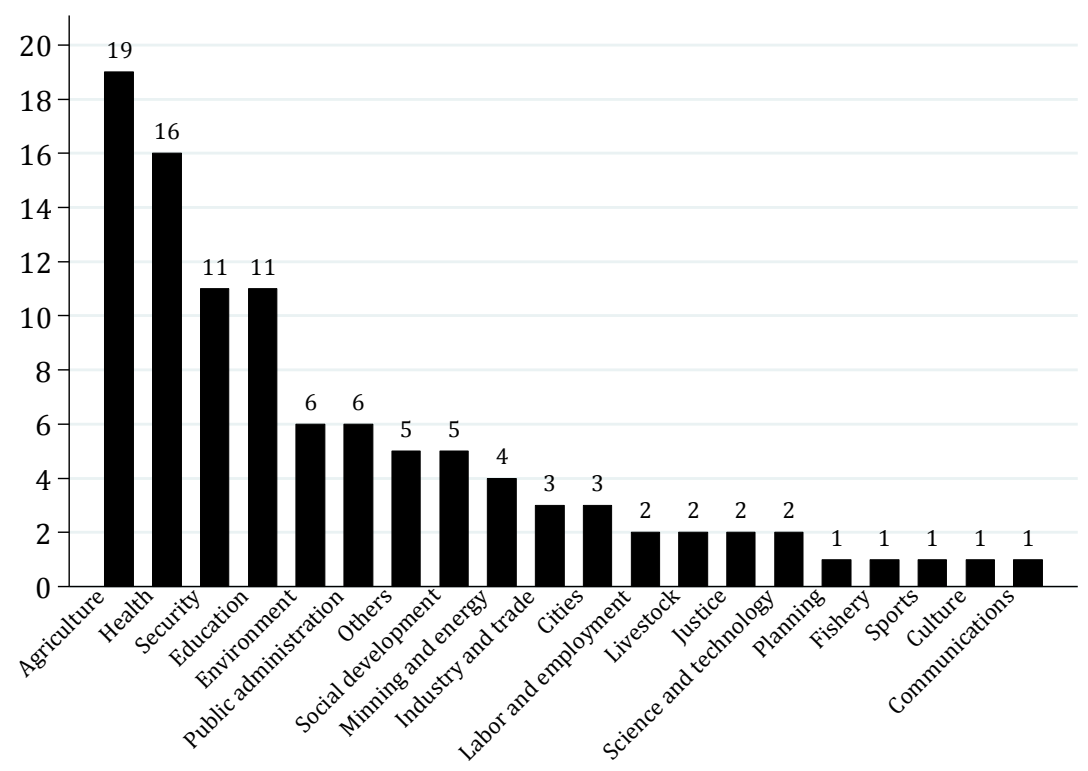

Source: ABC, 2014

\section{Data, methods and research design}

This article analyzes if there exists a relationship between the bilateral foreign aid given by Brazil and the composition of its bloc in international financial institutions. The variables of interest are the volume of aid supplied by Brazil between 2003 and 2010 and the participation (or not) of countries in the Brazilian bloc in the Executive Boards of the IMF and the World Bank. The hypothesis raised is that participation in the coalitions led by Brazil in the IMF and the World Bank impact in a positive manner the receipt of Brazilian foreign aid.

In order to test this hypothesis, a dataset ${ }^{18}$ was developed in cross-sectional format, using the data from AidData 0.3, the World Development Indicators (WDI) of the World Bank, data from the websites of the Ministry of Foreign Relations, the

18 A dataset was also built in panel format, aggregating 201 countries over the years 2003 to 2010 independent of participation in the IMF and the World Bank. Models were run in order to correct eventual problems with autocorrelation and heteroskedasticity, employing the Panel Correct Standard Errors (PCSE) method, including a lag ( $\mathrm{t}-1)$ of the dependent variable in the regression in all models (BECK and KATZ, 1995). Due to the "membro" variable displaying little variation in the period analyzed, being practically the same countries in the Brazilian coalition between 2003 and 2010, and due to the fact that the models estimated in the cross-sectional dataset displayed better measures of fit, only the latter models were chosen for this article, with the others presented in the appendices, available on BPSR website at bpsr.org.br/files/archives/Dataset_Apolinario. The results over the two models are also similar, with the difference being that in the models estimated from panel data, the "member" variable loses statistical significance with the inclusion of regional dummies for continents.

$$
\text { (2016) } 10(3) \quad \text { e0006-16/29 }
$$


IMF, the World Bank and the AliceWeb tool developed by MDIC. The dataset aggregates data on 210 countries over the years between 2003 and 2010. In order to verify if the countries in the Brazilian bloc in the IMF and the World Bank receive more Brazilian foreign aid than those who do not participate, a dichotomous dummy variable was created, coded as "1" for observations in which a state was present as a member of the Brazilian bloc and "0" otherwise.

In this period, nine countries joined the Brazilian coalition: the Dominican Republic, Colombia, Ecuador, Guyana, Haiti, Panama, the Philippines, Suriname and Trinidad and Tobago. Following the research design of Vreeland (2011), Colombia was coded as "0" on the grounds that this country had already received as compensation the chair of vice-director for supporting Brazil in the elections for executive directors. The models were also run with Colombia coded as " 1 " and the results stayed the same.

Due to the fact that the variables referring to participation in the Brazilian IMF and World Bank coalitions are very similar, in as much as there is practically no variation in the composition of the coalitions in both cases, the single variable "member" was chosen to refer to participation in both of the organizations. Thus, there are eight observations in relation to participation in the Brazilian coalition in the IMF and/or the World Bank and 202 observations of non-participation.

Note that Brazil only came to provide foreign aid in a systematic fashion in the last decade, while the majority of the countries that compose the Brazilian bloc have participated in it for a longer time. The idea is that participation in the Brazilian coalition is one of the determinants for receipt of foreign aid, such that the countries that make up the Brazilian bloc in international financial institutions are compensated from the moment that Brazil came to provide aid in the international arena in order to keep these countries inside its sphere of influence in these organizations.

Although this research dialogues with the analysis by Vreeland (2011) on the Swiss case, it should be noted that the cases and theoretical models are different. Even if, on the one hand, Switzerland has been providing foreign aid for decades, its coalition was formed only at the start of the 1990s. Yet the Brazilian case is the inverse, inasmuch as its coalition exists since the founding of these 
institutions, passing through few changes, whereas Brazil only came to provide aid in a substantial way during the second Lula government.

In order to test the formulated hypothesis, regressions were run, using the Ordinary Least Squares method for data distributed in cross sectional format, where the dependent variable refers to Brazilian foreign aid. In order to operationalize this variable, the natural logarithm of the total for foreign aid provided by Brazil was used, for each country in the sample during the considered $\operatorname{period}^{19}$.

The variables used as controls were those from the provision of Brazilian foreign aid guidelines, such as: the number of Presidential visits at bilateral level (viagens) to another country; the number of visits undertaken by state and government leaders to Brazil (recebidas); a variable for the countries that make up the Community of the Portuguese-speaking Countries (cplp); and regional variables for Africa (africa), South America (amsul) and Central America (amcentral).

Variables taken from the literature on the determinants for receiving foreign aid were also used, adapted substantively to the Brazilian case, such as per capita income, the volume of trade with Brazil and the size of the country. The variable for income per capita (ln_percapita) - operationalized as the natural logarithm of the average gross national product per capita for each country between 2003 and 2010 in constant US\$2005 - is used in order to capture the effects referring to the recipient's needs. The variable for the volume of Brazilian trade (ln_comercio) - operationalized as the natural logarithm of the sum of the total of Brazilian imports and exports in dollars for each country in the sample between 2003 and 2010 - is used to capture possible commercial interests connected to the provision of Brazilian foreign aid. Table 01 displays the principal descriptive statistics of the variables mentioned above.

19 The natural logarithm of the variable was used to make the distribution of the variable approximate a normal distribution. Due to the fact it is impossible to take the log of " 0 ", firstly, the "1"s referring to foreign aid were summed and the log was subsequently taken. 
Table 01. Descriptive statistics (2003-2010)

\begin{tabular}{lcccccc}
\hline Variable & $\mathrm{N}$ & Mean & Std. Dev. & Min. & Max. & Type \\
\hline Africa & 210 & 0.26 & 0.44 & 0 & 01 & Binary \\
Aid & 210 & 830,596 & $4.548,073$ & 0 & $58.5 \mathrm{mi}$ & U\$ 2011 const. \\
Centralamerica & 210 & 0.11 & 0.32 & 0 & 01 & Binary \\
Cplp & 210 & 0.04 & 0.19 & 0 & 01 & Binary \\
ln_aid & 210 & 5.08 & 6.25 & 0 & 17.88 & Log \\
ln_percapita & 198 & 8.23 & 1.66 & 4.99 & 11.82 & Log \\
ln_pop & 209 & 15.18 & 2.3 & 9.18 & 20.99 & Log \\
ln_trade & 203 & 19.96 & 3.11 & 11.42 & 26.4 & Log \\
Member & 210 & 0.038 & 0.19 & 0 & 01 & Binary \\
Memberimf & 210 & 0.03 & 0.18 & 0 & 01 & Binary \\
Memberwb & 210 & 0.03 & 0.18 & 0 & 01 & Binary \\
Percapita & 198 & 12378.6 & 19759.6 & 147.8 & 135611 & U\$ 2005 const. \\
Pop & 209 & $30.6 \mathrm{mi}$ & $124 \mathrm{mi}$ & 9731.12 & $1.31 \mathrm{bi}$ & Total No \\
Recvisits & 210 & 1.31 & 2.51 & 0 & 20 & Count \\
Southamerica & 210 & 0.06 & 0.23 & 0 & 01 & Binary \\
Trade & 210 & $8.77 \mathrm{bi}$ & $28.7 \mathrm{bi}$ & 0 & $291 \mathrm{bi}$ & U\$ 2011 const. \\
Trips & 210 & 0.82 & 1.69 & 0 & 13 & Count \\
\hline
\end{tabular}

Sources: AidData 0.3; AliceWeb/MDIC; World Development Indicators; websites of Itamaraty, IMF and World Bank.

Following this, table 02 shows the average of the values of Brazilian bilateral foreign aid received by each dichotomous variable considered. The first two columns show the average of the aid received by countries that compose the group referring to Africa, South and Central America, the CPLP countries and the Brazilian coalition in the IMF and the World Bank, considering all 210 countries in the sample. The final two columns of the table display the same information, but considering only the countries that received bilateral Brazilian foreign aid in the period.

Table 02. Mean of Brazilian bilateral foreign aid over Africa, South America, Central America, CPLP and Brazilian coalition in IMF and World Bank (2003-2010)

\begin{tabular}{lcccc}
\hline & \multicolumn{2}{c}{ Member } & Non-member & \multicolumn{2}{c}{ Member } & Non-member \\
& \multicolumn{2}{c}{ All countries } & \multicolumn{2}{c}{ Receiving aid countries } \\
\hline Africa & $\mathrm{n}=54$ & $\mathrm{n}=156$ & $\mathrm{n}=40$ & $\mathrm{n}=46$ \\
& $\$ 2.265,657$ & $\$ 333,844$ & $\$ 3.058,637$ & $\$ 1.132,168$ \\
Brazilian Coalition & $\mathrm{n}=8$ & $\mathrm{n}=202$ & $\mathrm{n}=8$ & $\mathrm{n}=78$ \\
& $\$ 2.355,290$ & $\$ 770,212$ & $\$ 2.355,290$ & $\$ 1.994,652$ \\
Central America & $\mathrm{n}=24$ & $\mathrm{n}=186$ & $\mathrm{n}=20$ & $\mathrm{n}=66$ \\
& $\$ 1.026,789$ & $\$ 805,280$ & $\$ 1.232,147$ & $\$ 2.269,428$ \\
CPLP & $\mathrm{n}=8$ & $\mathrm{n}=202$ & $\mathrm{n}=6$ & $\mathrm{n}=80$ \\
& $\$ 14.500,000$ & $\$ 290,393$ & $\$ 19.300,000$ & $\$ 733,243$ \\
South America & $\mathrm{n}=12$ & $\mathrm{n}=198$ & $\mathrm{n}=12$ & $\mathrm{n}=74$ \\
& $\$ 1.081,187$ & $\$ 815,408$ & $\$ 1.081,187$ & $\$ 2.181,769$ \\
\hline
\end{tabular}

Sources: AidData 3.0. 


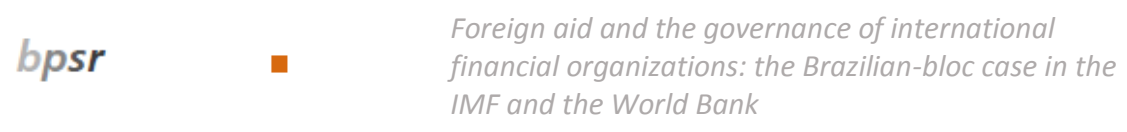

The information above gives an idea of the general panorama of Brazilian foreign aid. Although it is merely a descriptive analysis, these data point to the importance of controlling for the effect of these variables in the estimation of econometric models, insofar as they reveal indices of the relation between the supply of Brazilian foreign aid and each one of these dichotomous variables, including the variable of interest in this study, "member". Hence, it is expected that these variables will have positive coefficients in relation to the dependent variable, Brazilian bilateral foreign aid, in the regression analysis.

\section{Empirical analysis}

Regressions were run for the dependent variable referring to foreign aid, in order to see if participation in the coalitions led by Brazil in the IMF and the World Bank is one of the determinants for the receipt of Brazilian foreign aid. Firstly, a linear bivariate regression was run, analyzing the effect of the independent variable for coalition participation on the dependent variable. Subsequently, multivariate linear regressions were used, including the control variables.

The first model considered only the independent variable for participation in the Brazilian bloc in international financial institutions. In the second model, the variables included refer to diplomatic activities, being based on the Brazilian foreign policy guidelines for the signing of cooperation agreements. This model includes the dichotomous variable for those countries which form the CPLP; the variable referring to the total number of bilateral visits made by President Lula to each country in the sample, and a variable referring to the number of visits by leaders of state and government to Brazil. The third model considers the same variables, with the addition of binary regional variables for Africa, South and Central America, in order to control for regional effects in the receipt of Brazilian foreign aid.

In the fourth model, variables that are prominent in the international literature on the allocation of foreign aid were used, such as indicators relative to the volume of Brazilian trade in relation to each country in the sample, the level of development of the recipient countries and the size of these countries. The fifth model considers, besides these variables taken from the international literature, the variables taken from the guidelines on the signing of agreements of cooperation 
by Brazil, with the exception of dichotomous regional variables. Finally, the sixth model considers, besides the "member" variable, all the controls used in the preceding models. Table 03 displays the results of the models estimated.

Table 03. Impact of Brazilian coalition membership on Brazilian bilateral foreign aid (2003-2010)

\begin{tabular}{|c|c|c|c|c|c|c|}
\hline ln_aid & (1) & (2) & (3) & (4) & (5) & (6) \\
\hline Member & $\begin{array}{c}7.718^{* * *} \\
(0.867)\end{array}$ & $\begin{array}{c}7.121^{* * *} \\
(0.942)\end{array}$ & $\begin{array}{c}3.928^{* * *} \\
(1.098)\end{array}$ & $\begin{array}{c}5.283^{* * *} \\
(0.875)\end{array}$ & $\begin{array}{c}5.843^{* * *} \\
(0.873)\end{array}$ & $\begin{array}{l}2.607^{*} \\
(1.100)\end{array}$ \\
\hline Cplp & & $\begin{array}{l}6.802^{*} \\
(2.631)\end{array}$ & $\begin{array}{l}5.648^{* *} \\
(2.068)\end{array}$ & & $\begin{array}{l}5.450^{* *} \\
(1.804)\end{array}$ & $\begin{array}{l}6.576^{* *} \\
(2.037)\end{array}$ \\
\hline Trips & & $\begin{array}{c}0.788 \\
(0.535)\end{array}$ & $\begin{array}{l}0.726^{*} \\
(0.319)\end{array}$ & & $\begin{array}{l}1.145^{* *} \\
(0.431)\end{array}$ & $\begin{array}{c}0.545 \\
(0.305)\end{array}$ \\
\hline Recvisits & & $\begin{array}{c}0.289 \\
(0.371)\end{array}$ & $\begin{array}{l}0.0325 \\
(0.314)\end{array}$ & & $\begin{array}{l}-0.0604 \\
(0.304)\end{array}$ & $\begin{array}{l}-0.123 \\
(0.315)\end{array}$ \\
\hline Africa & & & $\begin{array}{c}7.719^{* * *} \\
(0.840)\end{array}$ & & & $\begin{array}{c}7.383^{* * *} \\
(0.927)\end{array}$ \\
\hline Southamerica & & & $\begin{array}{c}7.328 * * * \\
(1.770)\end{array}$ & & & $\begin{array}{c}9.629 * * * \\
(2.364)\end{array}$ \\
\hline Centralamerica & & & $\begin{array}{c}8.375^{* * *} \\
(1.070)\end{array}$ & & & $\begin{array}{c}10.39 * * * \\
(1.178)\end{array}$ \\
\hline ln_percapita & & & & $\begin{array}{c}-2.664^{* * *} \\
(0.369)\end{array}$ & $\begin{array}{c}-2.398 * * * \\
(0.356)\end{array}$ & $\begin{array}{c}-0.200 \\
(0.354)\end{array}$ \\
\hline In_trade & & & & $\begin{array}{c}1.242^{* * *} \\
(0.256)\end{array}$ & $\begin{array}{l}0.858^{* *} \\
(0.257)\end{array}$ & $\begin{array}{l}-0.104 \\
(0.228)\end{array}$ \\
\hline ln_pop & & & & $\begin{array}{c}-1.194^{* * *} \\
(0.356)\end{array}$ & $\begin{array}{c}-1.048^{* *} \\
(0.343)\end{array}$ & $\begin{array}{c}0.527 \\
(0.334)\end{array}$ \\
\hline Cons & $\begin{array}{c}4.790^{* * *} \\
(0.436)\end{array}$ & $\begin{array}{c}3.524^{* * *} \\
(0.439)\end{array}$ & $\begin{array}{l}0.718^{*} \\
(0.331)\end{array}$ & $\begin{array}{c}20.31^{* * *} \\
(4.413)\end{array}$ & $\begin{array}{c}22.44^{* * *} \\
(4.364)\end{array}$ & $\begin{array}{l}-3.419 \\
(4.155)\end{array}$ \\
\hline $\begin{array}{l}\mathrm{N} \\
R^{2}\end{array}$ & $\begin{array}{c}210 \\
0.056\end{array}$ & 210 & $\begin{array}{c}210 \\
0.574\end{array}$ & $\begin{array}{c}193 \\
0289\end{array}$ & $\begin{array}{c}193 \\
0.395\end{array}$ & $\begin{array}{c}193 \\
0650\end{array}$ \\
\hline
\end{tabular}

Sources: Dataset_Apolinario.

Notes: ${ }^{*} \mathrm{p}<0.05 /{ }^{* *} \mathrm{p}<0.01 /{ }^{* * *} \mathrm{p}<0.001$. Robust standard errors in parentheses. 


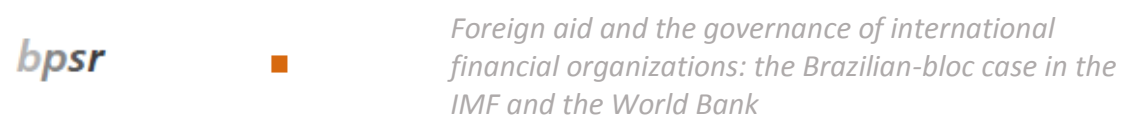

The "member" variable is statistically significant in all the models estimated, indicating that during this period the fact that a country supports Brazil in international financial institutions - the IMF and the World Bank - impacts in a positive manner the volume of Brazilian foreign aid received. In the fifth model, which considers the variables taken from the guidelines for the provision of Brazilian foreign aid, with the exception of regional factors and those from the international literature on the determinants of foreign aid, the variable for participation in the Brazilian coalition is estimated as having a positive coefficient of 5.84, statistically significant at the 0.001 level. Yet, in the sixth model, the "member" variable has a coefficient of 2.64 and is statistically significant at the 0.05 level.

Substantively, because we are dealing with a log-level relation, in which the dependent variable is operationalized by means of the natural logarithm of the original values, the estimated impact of the coefficients should be read as 100 times the estimate of the parameter (beta) \% in relation to the dependent variable (GUJARATI, 2006). Thus, the impact of the "member" variable on the volume of foreign aid given by Brazil, compared to a non-member country, increases by $584 \%$ the volume of Brazilian foreign aid in model 5 and by $261 \%$ in model 06 , given that the other factors are held constant. Considering a $95 \%$ confidence interval, this value varies between $412 \%$ and $756 \%$ in the fifth model and between $43 \%$ and $477 \%$ in model 06 .

Regarding the control variables taken from the guidelines for the provision of Brazilian foreign aid, it is worth noting the importance of African, South American, Central American and CPLP countries for the Brazilian foreign policy. The variables "africa", "amsul" and "amcentral" show positive coefficients of a high magnitude (7.83, 9.62 and 10.39, respectively) and these are statistically significant at the 0.001 level, evidence for the importance of regional factors in the realization of cooperation agreements with Brazil.

The variable "cplp" has a positive coefficient, which is statistically significant at the 0.01 level (5.45 in model 05 and 6.57 in model 06), highlighting the importance of this group in relation to Brazilian cooperation policy. Yet the variables for bilateral presidential trips made and received do not display statistical significance, although the variable referring to the bilateral visits of President Lula approaches statistical significance in the models that do not include regional factors (coefficient equal to 1.14 in model 05). 
In relation to the variables from the international literature on foreign aid, although the three variables do not display statistical significance in the final model, which considers regional factors, these variables are statistically significant in the preceding models. In models 04 and 05 , "In_percapita" is statistically at the 0.001 , with a negative coefficient, indicating that the more developed a country, the less foreign aid it receives from the Brazilian government. The "ln_pop" variable shows statistical significance at the 0.001 and 0.01 levels, with negative coefficients, showing that the larger a country, the less foreign aid it receives from Brazil. Lastly, the "In_comercio" variable is positively signed and achieves statistical significance at the 0.01 and 0.001 levels, signifying that the greater the commercial relationship with Brazil during the period considered, the more Brazilian foreign aid the country receives, suggesting that there are commercial motivations in the provision of foreign aid on Brazil's part.

In the two cases, as we are dealing with log-log relations, the impact estimated by the coefficients should be read as the variation of $01 \%$ in the independent variable leads to a variation of (beta) \% in the dependent variable (GUJARATI, 2006). Therefore, in the fifth model, the increase of $01 \%$ in the per capita income of a country lessens the Brazilian foreign aid it receives by $2.39 \%$; an increase of $01 \%$ in trade increases the aid received by $0.85 \%$, other factors held constant.

\section{Conclusion}

This article analyzed if the fact that a country belongs to the coalitions led by Brazil in the IMF and the World Bank influences the volume of Brazilian foreign aid received.

The results confirm the hypothesis that there is a positive relation between Brazilian foreign aid and the composition of the Brazilian bloc in the IMF and the World Bank. It was shown that the fact that a country supports Brazil in international financial institutions translates to a positive shift in the amount of Brazilian foreign aid received by each country during the period considered. These results highlight important aspects of international politics, insofar as they demonstrate the diplomatic objectives of Brazilian foreign aid.

For the inferential analysis, this research employed the data available until the present moment on Brazilian foreign aid. It is worth noting that the data on Brazilian foreign aid taken from the AidData 3.0 project are still incomplete and that the datasets 
from IPEA are still unavailable to the general public. In the future, it would be interesting to undertake analysis utilizing the official data supplied by the government to see if the results differ.

This exploratory research has sought to dialogue with the literatures on foreign aid and on the governance of international financial institutions. There are various avenues for future research in both areas. Firstly, in relation to the literature that deals with the role of emerging states in the governance of the IMF and the World Bank, although it has been shown that these countries are compensated financially for supporting Brazil in these organizations, the reasons for support before the country became a donor in the international arena have not been determined. In a future research agenda, it would be interesting to carry out interviews with staff who have served in these institutions in order to list the initial motives for the formation of the Brazilian bloc and for its continuity and change.

In relation to a research agenda on the foreign aid provided by emerging countries, this study has sought to investigate the determinants for receiving Brazilian aid. Going beyond descriptive analysis, a determinant until now little explored was presented. This study showed that the Brazilian government aimed for diplomatic objectives with its foreign aid policy, in this case, the expansion of its influence in the governance of the IMF and the World Bank. A hypothesis to be tested in the future is if this fact was due to competition arising from the increase in participation quotas of other emerging countries in these organizations.

It would also be interesting to analyze in future work the relation between the aid provided by Brazil and the positions of the recipient countries relative to Brazil in other international organizations, such the the United Nations General Assembly and the World Trade Organization, for example. It is also necessary to investigate what the relation is between the cooperation agreements signed by Brazil and the performance of Brazilian multinationals in these countries, according to when data on Brazilian Foreign Direct Investment is made public. It is noteworthy that these companies were the largest financial backers of electoral campaigns in the most recent elections and currently face serious charges of corruption. Thus, it would be interesting to analyze the performance of private actors in the implementation of these policies in order to check if different cooperation projects serve the interests of different actors in the domestic context. 
This research has considered the period until 2010 because of the availability of data until this moment. The AidData project only possesses data until this time and IPEA have as yet not released the report for the period 2010-2015. Faced with the current crisis that the BRICS are experiencing, above all Brazil, it is necessary to undertake more studies on the politics of Brazilian cooperation. In particular, in order to investigate what the objectives of these policies are for the Brazilian state, which groups primarily benefit with these policies, and principally, if this phenomenon was a government policy and tends to cease with the eventual change of power in the Executive branch, or if it is a state policy, and as such, if it has consolidated during successive administrations.

Translated by Robert McDonnell

Submitted on October 04, 2015

Accepted on July 17, 2016

\section{References}

AGÊNCIA BRASILEIRA DE COOPERAÇÃO (2014), Available at <http://www.abc.gov.br/> Accessed on March 10, 2016.

AIDDATA 3.0 (2011), Available at <http://aiddata.org/data-user-guide\#citing_aiddata > Acessed on March 10, 2016.

ALESINA, Alberto and DOLLAR, David (2000), Who gives aid to whom and why? Journal of Economic Growth. Vol. 05, № 01, pp. 33-63.

BEARCE, David H. and TIRONE, Daniel C. (2010), Foreign aid effectiveness and the strategic goals of donor governments. The Journal of Politics. Vol. 72, № 3, pp. 837851.

BECK, Nathaniel and KATZ, Jonathan N. (1995), What to do (and not to do) with time series cross section data. American Political Science Review. Vol. 89, № 03, pp. 634647.

BERMEO, Sarah Blodgett (2008), Foreign aid, foreign policy, and strategic development. PhD Dissertation. Princeton University.

BERTHÉLEMY, Jean-Claude. 2006. “Bilateral Donors' Interest vs. Recipients' Development Motives in Aid Allocation: Do All Donors Behave the Same?" Review of Development Economics. Vol. 10, № 02, pp. 179-94.

DREHER, Axel; NUNNENKAMP, Peter, and THIELE, Rainer (2008), Does US aid buy UN general assembly votes? A disaggregated analysis. Public Choice. Vol. 136, № 01, pp. 139-164. 
FARIA, Carlos Aurélio Pimenta de and PARADIS, Clarisse Goulart (2013), Humanism and solidarity in Brazilian foreign policy under Lula (2003-2010): theory and practice. Brazilian Political Science Review. Vol. 07, № 02, pp. 08-36.

GUJARATI, Damodar N. (2006), Econometria Básica. 4a Campus/Elsevier. 920 pp..

HIRST, Monica (2011), Brazil's renewed responsibilities in cooperation for development and international security. In Engagement on development and security: New actors, new debates. Edited by SHERMAN, Jake, GLEASON, Megan M., SIDHU, W.P.S., \& JONES, Bruce. New York: Center on International Cooperation. pp. 31-40.

HIRST, Monica; LIMA, Maria Regina Soares de, and PINHEIRO, Letícia (2010), A política externa brasileira em tempos de novos horizontes e desafios. Nueva Sociedad. pp. $22-41$.

INTERNATIONAL MONETARY FUND (2015), Available at <http://www.imf.org/> Accessed on March 10, 2016.

IPEA (2010), Cooperação brasileira para o desenvolvimento internacional 2005-2009. Brasília:

Ipea. http://www.ipea.gov.br/portal/index.php?option=com_content\&view=article\&id=6 747

IPEA. (2013), Cooperação brasileira para o desenvolvimento internacional 2010. Brasília: Ipea. http://www.ipea.gov.br/portal/index.php?option=com_content\&view=article\&id=1 9070

LANCASTER, Carol (2007), Foreign aid: diplomacy, development, domestic politics. Chicago: The University of Chicago Press. 288 pp..

LEITE, Isabel Cristina (2012), Cooperação Sul-Sul: conceito, história e marcos interpretativos. Observador On-line. Vol. 07, № 03, pp. 01-40.

LEMONDE DIPLOMATIQUE (2014), Brasil, um país doador. Available at <http://www.diplomatique.org.br/artigo.php?id=910> Accessed on March 10, 2016.

MCKINLAY, Robert D. and LITTLE, Richard (1977), A foreign policy model of U.S. bilateral aid allocation. World Politics. Vol. 30, № 01, pp. 58-86.

MILANI, Carlos R. S. (2014), Instituições bilaterais dos países do Comitê de assistência ao desenvolvimento. In: Repensando as relações internacionais. Edited by SOUZA, André de Mello e. Brasilia: IPEA.

MINISTÉRIO DO DESENVOLVIMENTO, INDÚSTRIA E COMÉRCIO EXTERIOR (2014), Available at <http://www.mdic.gov.br> Accessed on March 10, 2016. 
OCDE (2016), Organização para a cooperação e desenvolvimento econômico. Available at <http://stats.oecd.org/glossary/detail.asp?ID=6043> Accessed on March 10, 2016.

OLIVEIRA, Amancio Jorge Silva Júnior de and ONUKI, Janina (2012), South-South cooperation and Brazilian foreign policy. Foreign Policy Research Center Journal. Vol. 03, pp. 80-99.

PINHEIRO, Letícia and GAIO, Gabriele (2014), Cooperation for development, Brazilian regional leadership and global protagonism. Brazilian Political Science Review. Vol 08, № 02, pp. 59-93.

PUENTE, Carlos Alfonso Iglesias (2010), A cooperação técnica horizontal brasileira como instrumento da política externa: a evolução da cooperação técnica com países em desenvolvimento - CTPD - no período 1995-2005. Brasília: Fundação Alexandre de Gusmão/MRE. FUNAG. 340 pp..

SCHRAEDER, Peter J.; HOOK, Steven W., and TAYLOR, BRUCE (1998), Clarifying the foreign aid puzzle: a comparison of American, Japanese, French, and Swedish aid flows. World Politics. Vol. 50, № 02, pp. 294-323.

SECRETARIA DE COMÉRCIO EXTERIOR, MINISTÉRIO DO DESENVOLVIMENTO, INDÚSTRIA E COMÉRCIO EXTERIOR (2014), Sistema de análise das informações de comércio exterior via Internet (ALICEweb). Available at: <http://aliceweb.desenvolvimento.gov.br/> Accessed on March 10, 2016.

SOUZA, André de Mello e (2012), A cooperação para o desenvolvimento Sul-Sul: os casos do Brasil, da Índia e da China. Cadernos Adenauer. pp. 75-88.

THE ECONOMIST (2010), Brazil's foreign-aid programme: speak softly and carry a blank cheque. Available at< http://www.economist.com/node/16592455> Accesed on March 10, 2016.

THE WORLD BANK (2012), World development indicators. Washington, D.C.: the World Bank. Available at <http://data.worldbank.org/data-catalog/world-developmentindicators $>$ Accessed on March 10, 2016.

VIANA, Suhayla Mohamed Khalil (2015), Cooperação internacional para o desenvolvimento e interesses organizados: os atores privados na cooperação técnica entre países em desenvolvimento brasileira. Doctoral Thesis. Universidade de São Paulo.

VIGEVANI, Tullo and CEPALUNI, Gabriel (2007), A política externa de Lula da Silva: a estratégia da autonomia pela diversificação. Contexto internacional. Vol. 29, № 02, pp. 273-335.

VREELAND, James Raymond (2011), Foreign aid and global governance: buying bretton woods - the Swiss-bloc case. Review of International Organization. Vol. 06, № 03/04, pp. 369-391. 
WOODS, Ngaire and LOMBARDI, Domenico (2005), Effective representation and the role of coalitions within the IMF. Working Paper 17. Oxford: Global Economic Governance.

WORLD BANK GROUP (2014), Available at <http://www.worldbank.org> Accessed on March 2016.

\section{Annex}

\section{Variables}

Africa: dummy variable for African countries.

Aid: total of Brazilian bilateral foreign aid to each sample country between the years 2003 and 2010 in dollars (constant U\$ 2011). Source: AidData 3.0, dataset formed through the merger of two prior initiatives: Project-Level Aid (PLAID) and Accessible Information on Development Activities (AiDA).

Centralamerica: dummy variable for Central American countries.

Cplp: dummy variable regarding the members of the Community of Portuguese Speaking Countries.

ln_aid: natural logarithm of the total of Brazilian bilateral foreign aid between the years 2003 and 2010.

ln_percapita: level of economic development measured as the natural logarithm of the variable related to the per capita income mean of the each sample country between the years 2003 and 2010 .

ln_pop: variable utilized in order to control to the size of the aid receivers. Coded as the natural logarithm of the sample countries populations mean.

ln_trade: natural logarithm of the total of Brazilian exports plus imports to each country between the years 2003 and 2010 (constant U\$2011).

Member: dummy variable coded as 01 for the countries in the Brazilian coalitions in the Executive Boards of IMF and World Bank. Source: IMF/World Bank.

Memberimf: dummy variable coded as 01 for the countries in the Brazilian coalition the Executive Board of the IMF. Source IMF.

Memberwb: dummy variable coded as 01 for the countries in the Brazilian coalition the Executive Board of the World Bank. Source World Bank.

Percapita: level of economic development measured as the GDP per capita mean of each sample country between the years 2003 and 2010 (constant U\$ 2005). Source: World Development Indicators. 
Pop: average population size of each country between the years 2003 and 2010. Source: World Development Indicators.

Recvisits: total number of trips of heads of state' and government of each country sample to Brazil between the years 2003 and 2010. Source: Itamaraty.

Southamerica: dummy variable for South American countries.

Trade: total of Brazilian exports plus imports to each sample country between the years 2003 and 2010 (constant U\$ 2011). Source: Aliceweb.

Trips: total of bilateral Brazilian presidential trips to each country of the sample between the years 2003 and 2010. Source: Itamaraty. 